\title{
PELEMBAGAAN CULTURAL WAKAF DALAM MEWUJUDKAN WAKAF PRODUKTIF
}

\author{
Muhammad Junaidi dan B. Rini Heryati \\ Universitas Semarang Jawa Tengah \\ e-mail: institut.junaidi@gmail.com
}

\begin{abstract}
One of the dilemmas in the management of waqf that has not been completely answered by Waqf Law is the institutional side of waqf. Institutionalization of waqf is still perceived only from an institutional structure that is formalistic so as to make the productivity of waqf implementation still running in place. The aspect of institutionalization of waqf is not only seen on the side of the institutional structure formed by the government. The existence of a wakaf institution that is productive is of course based on the subjectivity in building community involvement in the legal space which has an indicator is the existence of society in designing productivity through institutional non-structural but still prioritize accountability.
\end{abstract}

Keywords: Institutionalization, Productive Waqf, Cultural Endowments

\section{Pendahuluan}

Ketentuan dalam pasal $28 \mathrm{E}$ ayat 1 dinyatakan bahwa Setiap orang bebas memeluk agama dan beribadat menurut agamanya, memilih pendidikan dan pengajaran, memilih pekerjaan, memilih kewarganegaraan, memilih tempat 


\section{Junaidi dan B. Rini}

tinggal di wilayah negara dan meninggalkannya, serta berhak kembali. Amanat dalam pasal 28 E ayat 1 setidaktidaknya memberikan ketegasan bahwa pemerintahlah yang mengatur tentang masalah agama yang pada gilirannya terjadinya ketertiban dalam menjalankan agama secara baik.

Penting sekali memang bagaimana hubungan antara agama dan negara dijalankan. Ernest Geliner memperbandingkan kegagalan Barat dalam mencari pemecahan ketegangan antara pusat keagamaan yang masih penuh aura magis, upacara, dan agak takhayul, tetapi hierarkhi yang sentralistik dengan arus reformasi dipinggirnya, yang kemudian berakhir pada jalan buntu. Tetapi justru hal ini yang mengakibatkan Iancarnya sekularisasi dan lahirnya civil society. Munculnya masyarakat sipil (civil society) berhubungan erat dengan munculnya borjuasi Eropa dalam masa system aturan yang absolut. Kelas ini terdiri dan para usahawan kapitalis yang mengalami kemajuan-kemajuan pada masa itu dan karenanya' menginginkan identitasnya tersendiri sebagai suatu kelas. Berbeda dengan dalam Stande yang ditegakkan oleh struktur otoritas yang memaksakan disiplin kepada para anggotanya, maka kelas borjuis ini menghendaki terjadinya kompetisi di antara anggotanya, yaitu perorangan dengan kepentingan-kepentingan sendiri. Melalui kesempatan berkompetisi itu diharapkan akan tercapai suatu keadaan ekuilibrium atau keseimbangan (Suteki, 2013: 151).

Peran agama tentunya tidak bisa dinafikkan dan dalam Undang-Undang Dasar Negara Republik Indonesia tahun 1945, posisi agama adalah pada bagian hak asasi manusia yang menjadi pengejewantahan eksistensi masyarakat dalam mewujudkan tertib hukum dan tertib dalam menjalankan proses kemasyarakatan. Salah satu wujud dalam peran pemerintah adalah dalam menjalankan eksistensi Wakaf sebagai bagian dari ajaran agama islam. 


\section{Pelembagaan Cultural Wakaf dalam Mewujudkan ...}

Lahirnya Undang-Undang Republik Indonesia Nomor 41 tahun 2004 tentang Wakaf menjadi bagaian yang penting dari eksistensi peran negara dalam menjalankan kewenangannya membuat ketertiban. Namun posisi masyarakat yang terus berkembang memungkinkan pengaturan dalam wakaf yang ada dalam Undang-Undang Republik Indonesia Nomor 41 tahun 2004 tentang Wakaf membutuhkan penyesuaian.

Masih banyaknya tanah wakaf yang belum tersertifikasi, menunjukkan bahwa akuntabilitas regulator dalam meningkatkan sertifikasi wakaf masih kurang. Hal ini juga menunjukkan bahwa kinerja regulator dalam membantu masyarakat untuk sertifikasi wakaf masih belum optimal. Sementara, program kerja utama regulator adalah semua harta wakaf sudah tersertifikasi, sehingga permasalahan-permasalahan pengalihan harta wakaf oleh ahli waris wakif dapat dikurangi. Permasalahan minimnya biaya APBN untuk sertifikasi wakaf membuat akuntabilitas regulator dalam mengelola wakaf di Indonesia kurang optimal. Permasalahan tanah wakaf yang masih banyak tidak memiliki sertifikat dan kurang produktif salah satunya menurut informan adalah sosialisasi Undang Undang wakaf yang masih kurang. Hal ini sesuai dengan hasil penelitian yang dilakukan Fathurrahman (2012) bahwa salah satu masalah yang dihadapi dalam pengelolaan tanah-tanah wakaf secara produktif adalah pengetahuan dan pemahaman nazhir terhadap peraturan perwakafan masih kurang. Sehingga, dapat disimpulkan bahwa sosialisasi mengenai pengelolaan wakaf yang terdapat dalam Undang Undang wakaf masih belum optimal dilakukan oleh regulator baik dari Badan Wakaf Indonesia maupun Kemenag (Huda, 2015: 490).

Permasalahan kelemahan wakaf tersebut tentunya harus menjadi respon atas lahirnya suatu sistem hukum yang kemudian dipergunakan di suatu negara tidak lepas 


\section{Junaidi dan B. Rini}

sejarah tradisi (hukum) dan budaya (hukum) legal culture yang dianut pada masyarakat tersebut. Bagi masyarakat yang menganggap praktik-praktik kebiasaan yang melembaga dan kemudian menjelma menjadi hukum, maka sistem hukumnya menjadi tradisi sistem hukum tidak tertulis sebagai bagian spirit of the people suatu bangsa. Sebaliknya ketika tradisi dan budaya tata tulis telah menjadi semangat kepastian hukum suatu bangsa, maka sistem hukumnya menjelma menjadi sistem hukum tertulis yang dikodifikasikan (Asikin, 2014: 78).

Hal ini juga termasuk dalam mewujudkan kelembagaan wakaf. Dominasi kelembagaan yang menjadi kelemahan dalam Undang-Undang Republik Indonesia Nomor 41 tahun 2004 tentang Wakaf yang masih didominasi lembaga formal sehingga menjadikan wakaf tidak mampu maksimal melahirkan produktifitas.

\section{Pembahasan}

Dalam penjelasan Undang-Undang Republik Indonesia Nomor 41 tahun 2004 tentang Wakaf ditegaskan bahwa Undang-Undang ini juga mengatur pembentukan Badan Wakaf Indonesia yang dapat mempunyai perwakilan di daerah sesuai dengan kebutuhan. Badan tersebut merupakan lembaga independen yang melaksanakan tugas di bidang perwakafan yang melakukan pembinaan terhadap Nazhir, melakukan pengelolaan dan pengembangan harta benda wakaf berskala nasional dan internasional, memberikan persetujuan atas perubahan peruntukan dan status harta benda wakaf, dan memberikan saran dan pertimbangan kepada Pemerintah dalam penyusunan kebijakan di bidang perwakafan.

Pertimbangan tersebut menjadikan orientasi dari kelembagaan wakaf menjadi wujud kelembagaan yang 


\section{Pelembagaan Cultural Wakaf dalam Mewujudkan ...}

bersifat formal, sehingga menjadikan produktifitas wakaf belum selayaknya memadai dalam mendukung produktifitas. Tentunya hal ini menjadi tantangan dan sekaligus problematika yang ada dalam UU wakaf. Kebutuhan untuk mencari solusi yang strategis sangatlah dibutuhkan sehingga menjadikan wakaf sesuai dengan kebutuhan.

Pengelolaan wakaf memiliki perbedaan dengan pengelolaan zakat ataupun bentuk sedekah pada umumnya. Pengelola wakaf harus menjaga agar harta wakaf tetap utuh namun diupayakan untuk dikembangkan supaya memberikan hasil yang maksimal kepada mauquf alaih. Sementara pengelolaan zakat, amil dapat mendistribusikan semua harta zakat yang terkumpul kepada mustahiq. Dari segi pengelolanya, antara zakat dengan wakaf juga berbeda. Zakat ditangani amil zakat. Amil dapat mendistribusikan semua harta zakat yang terkumpul kepada mustahiq. Oleh karena itu bentuk dan manajemen pengelolaan wakaf berbeda dengan zakat (Dahlan, 2016: 116).

Adanya kelembagaan yang bersifat mandiri dalam wakaf sebagai wujud dalam mendukung akselerasi produktifitas wakaf dirasa sangatlah penting. Urgensi tersebut terletak dari posisi wakaf yang sangatlah mengandalkan basis masyarakat untuk menggerakkannya. Hal inilah yang menjadi harapan dari pengelolaan wakaf sesuai dengan ajaran agama.

Upaya memposisikan kelembagaan wakaf tidak hanya bersifat formal dengan mempertimbangkan problema yang sifatnya jangka panjang dan lebih mendasar harus diselesaikan melalui solusi paradigmatik yakni pergeseran orientasi paradigma atas konsepsi negara hukum dan rechtsstaat menjadi the rule of law seperti yang banyak dikembangkan di negara-negara Anglo Saxon. Dengan paradigma ini, maka setiap upaya penegakan hukum akan 


\section{Junaidi dan B. Rini}

mampu melepaskan diri dari jebakan-jebakan formalitasprosedural serta mendorong para penegak hukum untuk kreatif dan berani menggali nilai-nilai keadilan serta menegakkan etika dan moral di dalam masyarakat dalam setiap penyelesaian kasus hukum. Perubahan paradigma ini harus diartikan pula sebagai upaya mengembalikan rasa keadilan dan moral sebagai sukma hukum yang akan dibangun untuk masa depan negara hukum Indonesia. Untuk melakukan penggeseran paradigma itu, kemungkinannya pada saat ini sudah lebih terbuka, sebab UUD 1945 hasil amandemen tidak lagi secara eksplisit menyebut "rechtsstaat" sebagai acuan negara hukum Indonesia. Istilah rechtsstaat yang dulu secara resmi terdapat di dalam Penjelasan UUD 1945 sekarang sudah tidak dicantumkan lagi.Setelab UUD 1945 mengalami empat kali perubahan (amandemen), Penjelasan UUD tersebut dihapuskan dan tidak lagi menjadi bagian dan UUD 1945. Sebagai gantinya, pada Pasal 1 ayat (3) UUD 1945 digariskan tentang negara hukum anutan Indonesia dengan bunyi ayat "Negara Indonesia adalah negara hukum" (Mahfud, 2013: 186).

Upaya memposisikan sistem negara hukum yang bukan hanya bersifat doktrinal akan menjadikan kelembagaan wakaf menjadi kuat. Namun tantangan terberat yang ada adalah kurang adanya orientasi yang jelas dalam UU Wakaf mengingat proses formalitas perundangundangan yang lebih mengakuisisi peran negara daripada peran masyarakat. Soetandyo Wignyosoebroto menyatakan bahwa positivisasi norma-norma hukum adalah suatu proses politik yang amat menentukan bagi perkembangan hukum sebagai suatu applied art. Ajaran hukum mi dengan jabaran-jabaran yang dikembangkan sebagai doktrin (seperti netralitas dan objektivitas dan impartialitas hukum) sudah demikian standar sejak awal abad 19. Ajaran mi pun kemudian diintroduksikan ke negara-negara jajahan Eropa 


\section{Pelembagaan Cultural Wakaf dalam Mewujudkan ...}

termasuk Indonesia. Dalam hal mi Soetandyo Wignyosoebroto' menyebutkan di negeri jajahan Hindia Belanda, doktrin-doktrin positivisme yang dikembangkan dan liberal legal justice mi telah dicoba dikembangkan lewat proses-proses replikasi. Dalam ranah legal formalism hukum dikonsepsikan terutama sebagai sarana kontrol sosial untuk menjamin kepastian agar perilaku selalu tetap dan dapat diprediksikan (Logika Normologik). Jadi, kajian utamanya sebagaimana di sebut Soetandyo Wignyosoebroto, adalah bermotivasi mengatur (to regulate). Norma hukum lalu menjadi pembenar atau penolak perilaku, atau dengan kata lain, norma hukum digunakan untuk melakukan justifikasi apakah suatu fakta memiliki dasar legitimasi atau tidak. Berdasarkan hal itu, maka pola berpikir yang digunakan untuk melakukan penelitiannya adalah silogisme deduktif. Akan tetapi perkembangan keilmuan tidak pernah berhenti. Pencarian kebenaran secara terus-menerus dalam dunia ilmu adalah keniscayaan. Demikianlah, perkembangan pemikiran dalam (ilmu) hukum tidak berhenti pada pemikiran tersebut di atas saja (Samekto, 2013: 56-57).

Upaya mengelaborasi berbagai macam doktrin teoritis dalam posisi negara mengatur hanya sebatas sebagai wujud partisipasi aktif dalam menjaga ketertiban. Unsur kepastian hukum bukan hanya dilihat dari posisi negara yang menjadikan kelembagaan wakaf secara formalitas.

Keberlakuan fungsi dalam negara dapat dilihat dari 2 (dua) aspek kekuasaan. Klasifikasi negara sesuai dengan fungsi kekuasaan yang diberlakukan tersebut sebagai berikut:

1) Negara di mana semua fungsi atau kekuasaan negara itu dipusatkan pada satu organ. Negara yang demikian ini adalah negara yang melaksanakan sistem absolut. Kemudian organnya itu sendiri bagaimanakah sifatnya, maksudnya organ negara itu, 


\section{Junaidi dan B. Rini}

yaitu organ negara yang tertinggi, dipegang atau dilaksanakan oleh beberapa orang. Hal ini terdapat tiga kemungkinan, yaitu:

a. Organ itu dapat bersifat tunggal, artinya organ yang tertinggi, serta kekuasaan negara yang tertinggi di dalam negara itu, hanya dipegang atau dilaksanakan oleh satu orang tunggal. Negara ini disebut monarki.

b. Organ itu dapat bersifat beberapa orang, artinya organ yang tertinggi, serta kekuasaan negara yang tertinggi di dalam negara itu, dipegang dan atau dilaksanakan oleh beberapa orang. Negara itu disebut aristokrasi atau oligarki.

c. Organ itu dapat bersifat jamak, artinya organ itu pada prinsipnya dipegang atau dilaksanakan oleh seluruh rakyat. Negara ini disebut demokrasi. Dengan demikian, maka kalau sistemnya itu, yaitu sistem absolutisme digabungkan atau dikombinasikan dengan sifat daripada organnya, akan kita dapatkan: 1) Monarki absolut. Yaitu negara di mana fungsi-fungsi atau kekuasaan negara itu dipusatkan pada satu organ, sedangkan organnya itu sendiri hanya dipegang oleh satu orang tunggal saja. 2) Aristokrasi atau oligarki absolut. Yaitu negara di mana fungsi-fungsi atau kekuasaan negara itu dipusatkan pada satu organ, sedangkan organnya itu sendiri dipegang oleh beberapa orang. 3) Demokrasi absolut. Yaitu negara di mana fungsi-fungsi atau kekuasaan negara itu dipusatkan pada satu organ, sedangkan organnya itu sendiri pada prinsipnya dipegang oleh seluruh rakyat. Negara ini juga disebut demokrasi murni

2) Negara di mana fungsi-fungsi atau kekuasaankekuasaan negara itu dipisah-pisahkan, pemisahan 
kekuasaan ini biasanya yang dianut adalah ajaran daripada Montesquieu, kemudian masing-masing kekuasaan itu diserahkan atau didistribusikan kepada beberapa organ. Sedangkan dalam hal ini yang penting atau yang menentukan adalah bagaimanakah sifat hubungan organ-organ itu satu sama lain. Khususnya sifat hubungan antara organ perundang-undangan dengan organ pelaksanaan yaitu pemerintah. (sifat hubungan antara badan legislatif dengan badan eksekutif) Oleh karena tergantung daripada inilah sifat atau sistem pemerintahannya, sedangkan sistem dari pada pemerintahan inilah yang selanjutnya akan menentukan bentuk daripada negaranya. Dimaksudkan dengan sifat daripada hubungan antara organorgan tersebut ialah, apakah organ-organ tersebut satu sama lain dapat saling memengaruhi ataukah tidak. Berdasarkan hal-hal tersebut di atas negara yang melaksanakan sistem pemisahan kekuasaan ini dapat diklasifikasikan menjadi: (a). Negara yang melaksanakan sistem pemisahan kekuasaan secara tegas, atau secara sempurna. Artinya masing-masing organ tersebut tidak dapat saling memengaruhi, khususnya antara badan legislatif dengan badan eksekutif. Sebagai contoh misalnya Amerika Serikat, disini kekuasaan perundang-undangan ada pada kongres, sedangkan kekuasaan pelaksanaan atau pemerintahan ada pada Presiden, dan di dalam konstitusinya dinyatakan dengan tegas pemisahan antara kedua kekuasaan tersebut, yang satu sama lain tidak dapat memengaruhi. negara ini disebut negara dengan sistem pemerintahan Presidensil. (b). Negara yang melaksanakan sistem pemisahan kekuasaan, dan masing-masing organ pemegang kekuasaan tersebut, 


\section{Junaidi dan B. Rini}

khususnya antara badan legislatif dengan badan eksekutif, dapat saling memengaruhi, atau saling berhubungan. Sifat hubungan antara kedua badan atau organ ini adalah bersifat politis, maksudnya kalau kebijaksanaan badan yang satu tidak mendapatkan persetujuan dan badan yang lain, badan tersebut dapat dibubarkan. Negara ini disebut negara dengan sistem Parlementer. (c). Negara yang melaksanakan sistem pemisahan kekuasaan, tetapi pada prinsipnya badan eksekutif itu hanya bersifat sebagai badan pelaksanaan atau badan pekerja saja dan pada apa yang telah diputuskan oleh badan legislatif. Dan disertai dengan pengawasan atau kontrol secara langsung dan rakyat, yaitu dengan sistem referendum. Negara ini disebut negara dengan sistem referendum.

Formalitas kelembagaan negara dapat dipahami dalam ketentuan Undang-Undang Republik Indonesia Nomor 41 tahun 2004 tentang Wakaf yang menjadi bagain yang penting dari eksistensi peran negara dalam menjalankan kewenangannya membuat ketertiban. Dalam Pasal 48 Badan Wakaf Indonesia berkedudukan di ibukota Negara Kesatuan Republik Indonesia dan dapat membentuk perwakilan di Provinsi dan/ atau Kabupaten/Kota sesuai dengan kebutuhan. Badan Wakaf Indonesia mempunyai tugas dan wewenang:

a. melakukan pembinaan terhadap Nazhir dalam mengelola dan mengembangkan harta benda wakaf;

b. melakukan pengelolaan dan pengembangan harta benda wakaf berskala nasional dan internasional;

c. memberikan persetujuan dan/atau izin atas perubahan peruntukan dan status harta benda wakaf;

d. memberhentikan dan mengganti Nazhir; 


\section{Pelembagaan Cultural Wakaf dalam Mewujudkan ...}

e. memberikan persetujuan atas penukaran harta benda wakaf;

f. memberikan saran dan pertimbangan kepada Pemerintah dalam penyusunan kebijakan di bidang perwakafan.

Secara struktural model kelembagaan badan wakaf indonesia yang demikian di atas bersifat struktural, akan tetapi dominasi peran pemerintah dalam menjamin wakaf sudah selayaknya dituntun untuk mengedepankan nilai cultural jika hal tersebut berlaku di indonesia terlebih jika kita pemehamai bahwa wakaf merupakan nilai-nilai jaminan beragama yang tumbuh dan berkembang dan cultur budaya masyarakat. Model ciri khas pengembangan demikian sangatlah menuntut modernisasi negara hukum.

Konsep kepastian hukum, dilihat dan perspektif sosiologis, semakin menjadi penting ketika hukum harus diletakkan dalam kerangka sistem sistem hukum modern. Sebagaimana diketahui, sistem hukum modern menunjuk pada sistem hukum yang dilahirkan dan tradisi pemikiran di Eropa Barat, khususnya sebagai implikasi dan Revolusi Perancis 1789. Ciri-ciri dan sistem hukum modern yang utama adalah:

a. Merupakan sistem hukum yang berasal dan tatanan sosial Eropa Barat pada Abad 19;

b. Sangat dipengaruhi paradigma positivisme dalam ilmu pengetahuan alam;

c. Rasional, lepas dan pengaruh Ketuhanan;

d. Meyakini bahwa hukum dapat dikonstruksi dan dikelola secara netral, tidak berpihak, impersonal, dan objektif;

e. Melindungi freedom-HAM; dan

f. Mendukung terciptanya kepastian untuk menjamin prediktabilitas (Samekto, 2013: 60). 


\section{Junaidi dan B. Rini}

Adanya kelembagaan yang non formal yang secara langsung tumbuh dan berkembang dari masyarakat terkait pengelolaan wakaf yang diantaranya lembaga masjid dan lain sebagainya akan menjadikan kelembagagaan wakaf sesuai dengan prinsip kemanfaatan bagi pelaksanaan wakaf yang ada di indonesia. Tentunya hal tersebut dapat berjalan dengan dukungan perubahan Undang-Undang Republik Indonesia Nomor 41 tahun 2004 tentang Wakaf.

Pertimbangan yang menjadi dasar kelembagaan cultural wakaf adalah pada posisi kepentingan sosial wakaf, misi yang dibawa meliputi sebagai berikut:

1. Keamanan umum;

2. Keamanan dan institusi-institusi sosial;

3. Moral umum;

4. Pengamanan sumber-sumber daya sosial

5. Kemajuan sosial dan

6. Kehidupan individu (pernyataan diri kesempatan kondisi kehidupan) (Raharjo, 1982: 266-267).

Apa yang disampaikan tersebut, merupakan pengaruh daripada ajaran John Locke yang berpendapat bahwa pemerintah harus melindungi hak-hak asasi rakyat, dan karena itu hak-hak asasi itu dicantumkan dalam undang-undang dasar (Kusnardi dan Saragih, 1994: 93). Jaminan cultural dalam membangun sistem wakaf merupakan ciri khas model politik pembangunan hukum pancasila. Dalam kedudunnya yang seperti itu dan dalam kaitan dengan politik pembangunan hukum maka Pancasila yang dimaksudkan sebagai dasar pencapaian tujuan negara yang melahirkan kaidah-kaidah penuntun hukum, yaitu:

1. Pertama, hukum yang dibuat di Indonesia haruslah bertujuan membangun dan menjamin integrasi negara dan bangsa Indonesia baik secara teritori maupun secara ideologi. Hukum di Indonesia tidak boleh memuat isi yang berpotensi (menyebabkan) 
Pelembagaan Cultural Wakaf dalam Mewujudkan ...

terjadinya disintegrasi wilayah maupun ideologi karena hal itu bertentangan dengan tujuan melindungi segenap bangsa dan seluruh tumpah darah Indonesia yang terikat dalam persatuan.

2. Kedua, hukum yang dibuat di Indonesia haruslah didasarkan pada Demokrasi dan Nomokrasi sekaligus. Demokrasi yang menjadi dasar politik (kerakyatan) menghendaki pembuatan hukum berdasar kesepakatan rakyat atau wakil-wakilnya yang dipilih secara sah baik melalui kesepakatan aklamasi maupun berdasar suara terbanyak jika mufakat bulat tak dapat dicapai sedangkan nomokrasi sebagai prinsip negara hukum menghendaki agar hukum-hukum di Indonesia dibuat berdasar substansi hukum yang secara filosofis sesuai dengan rechtside Pancasila serta dengan prosedur yang benar. Dengan demikian, hukum di Indonesia tak dapat dibuat berdasar "menang-menangan" jumlah pendukung semata tetapi juga harus mengalir filosofi Pancasila dan prosedur yang benar.

3. Ketiga, hukum yang dibuat di Indonesia harus ditujukan untuk membangun keadilan sosial bagi seluruh rakyat Indonesia. Dan penuntun yang demikian maka tidak dibenarkan muncul hukumhukum yang mendorong atau membiarkan terjadinya pertentangan sosial-ekonomi karena eksploitasi oleh yang kuat terhadap lemah tanpa perlindungan negara. Hukum-hukum di Indonesia harus mampu menjaga agar yang lemah tidak dibiarkan menghadapi sendiri pihak yang kuat yang sudah pasti akan dimenangkan oleh yang kuat. Oleh sebab itu, hukum di Indonesia harus mampu memberi proteksi khusus kelompok yang lemah agar mampu mempersempit jurang sosial-ekonomi yang 


\section{Junaidi dan B. Rini}

mungkin timbul karena eksploitasi oleh yang kuat terhadap yang lemah. Hukum yang berkeadilan dengan demikian, adalah hukum yang dimaksudkan untuk mempersempit jurang antara yang kuat dan yang lemah atau antara yang miskin dan yang kaya.

4. Keempat, hukum yang dibuat di Indonesia haruslah didasarkan pada toleransi beragama yang berkeadaban yakni hukum yang tidak mengistimewakan atau mendiskriminasi kelompok tertentu berdasar mayoritas atau minoritas pemeluk agama. Indonesia bukan negara agama (yang mendasarkan pada satu agama tertentu) dan bukan negara sekuler (yang tak perduli atau hampa spirit keagamaan). Indonesia sebagai Negara Pancasila adalah sebuah religious nation state, negara kebangsaan yang religius yang memberi perlindungan kuat terhadap setiap warganya untuk memeluk dan melaksanakan ajaran agamanya masing-masing tanpa boleh saling mengganggu, apalagi mengarah pada disintegrasi. Di dalam konsepsi yang demikian maka hukum negara tidak dapat mewajibkan berlakunya hukum agama, tetapi negara harus memfasilitasi, melindungi, dan menjadi alternati keamanannya jika warganya akan melaksanakan ajaran agama karena keyakinan dan kesadarannya sendiri. Jadi untuk hukum agama negara bukan mewajibkan pemberlakuannya menjadi hukum formal yang eksklusif melainkan memfasilitasi, melindungi, dan menjamin keamanan bagi yang ingin beribadah dengan penuh toleransi. Penegakan penuntun yang demikian sangat penting ditekankan karena masalah agama adalah masalah yang paling hak asasi sehingga tak seorang pun boleh memaksa atau dipaksa untuk memeluk atau tidak memeluk agama tertentu. Pelaksanaan ajaran agama, 


\section{Pelembagaan Cultural Wakaf dalam Mewujudkan ...}

dengan demikian, harus dilaksanakan dengan penuh toleransi dan berkeadaban (Mahfud, 2010: 52-54).

Oleh karenanya melalui konstruksi berfikir demikian kelembagaan wakaf perlu diarahakan untuk meluruskan orientasi yang jelas utamanya yang terdapat dalam UndangUndang Wakaf, mengingat proses formalitas perundangundangan yang lebih mengakuisisi peran negara daripada peran masyarakat. Pada sisi lain perlu adanya kelembagaan yang bersifat mandiri dalam wakaf sebagai wujud dalam mendukung akselerasi produktifitas wakaf dirasa sangatlah penting. Urgensi tersebut terletak dari posisi wakaf yang sangatlah mengandalkan basis masyarakat untuk menggerakkannya. Hal inilah yang menjadi harapan dari pengelolaan wakaf sesuai dengan ajaran agama.

Kebutuhan yang demikian sesuai dengan bagaimana seharusnya wajah sistem hukum dalam suatu negara hukum, ahli hukum terkenal yaitu Lon Fuller dalam bukunya The Morality of Law, menyebutkan sebagai berikut:

1. Hukum harus dituruti oleh semua orang, termasuk oleh penguasa negara.

2. Hukum harus dipublikasikan.

3. Hukum harus berlaku ke depan, bukan untuk berlaku surut.

4. Kaidah hukum harus ditulis secara jelas, sehingga dapat diketahui dan diterapkan secara benar.

5. Hukum harus menghindari dari kontradiksikontradiksi.

6. Hukum jangan mewajibkan sesuatu yang tidak mungkin dipenuhi.

7. Hukum harus bersifat konstan sehingga ada kepastian hukum. Tetapi hukum harus juga diubah jika situasi politik dan sosial telah berubah. 


\section{Junaidi dan B. Rini}

8. Tindakan para aparat pemerintah dan penegak hukum haruslah konsisten dengan hukum yang berlaku (Fuady, 2009: 9).

\section{Simpulan}

Formalitas pembentukan lembaga wakaf sangatlah perlu untuk tidak disandera pada bentuk lembaga formal. Hal tersebut mengingat wakaf sendiri adalah norma-norma yang tertuang menjadi wujud bagaian norma agama. Sehingga wujud lembaga wakaf yang bersifat produktif tentunya didasarkan pada subjektifitas dalam membangun keterlibatan masyarakat dalam ruang hukum yang memiliki indikator adalah eksistensi masyarakat dalam mendesaian produktifitas. Kelemahan dalam Undang-Undang Republik Indonesia Nomor 41 tahun 2004 tentang Wakaf perlu seharusnya diperbaiki yang dalam hal ini berkaitan utamanya reorientasi peraturan.

\section{Daftar Pustaka}

Fx Adji Samekto, Hukum Dalam Lintasan Sejarah, Indept Publishing, Jakarta, 2013.

Moh Kusnardi dan Bintan R Saragih. Ilmu Negara, Gaya Media Pratama, Jakarta, 1994.

Moh. Mahfud MD, Konstitusi dan Hukum Dalam Kontroversi Isu, Raja Grafindo Persada, Jakarta, 2010.

Moh. Mahfud MD, Perdebatan Hukum Tata NegaraPasca Amandemen Konstitusi, Raja Grafindo Persada, Jakarta, 2013.

Munir Fuady, Teori Negara Hukum Modern (Rechtstaat), Refika Aditama, Bandung, 2009. 


\section{Pelembagaan Cultural Wakaf dalam Mewujudkan ...}

Nurul Huda dkk, "Akuntabilitas Sebagai Sebuah Solusi Pengelolaan Wakaf", Jurnal Akuntansi Multiparadigma (Jamal) Vol. 5, No. 3, Hal. 345-510 Malang, Desember 2014 pISSN 2086-7603 eISSN 2089-5879

Rahmat Dahlan, "Analisis Kelembagaan Badan Wakaf Indonesia", Esensi: Jurnal Bisnis dan Manajemen, Vol. 6 (1), April 2016 P-ISSN: 2087-2038; E-ISSN: 2461-1182

Sadjipto Rahardjo, Ilmu Hukum, Alumni, Bandung, 1982.

Soehino, Ilmu Negara, Liberty, Yogyakarta, 1996.

Suteki, Desain Hukum Di Ruang Sosial, Thafa Media, Yogyakarta, 2013.

Undang-Undang Dasar Negara Republik Indonesai 1945

Undang-Undang Republik Indonesia Nomor 41 tahun 2004 tentang Wakaf

Zainal Asikin, Pengantar Tata Hukum Indonesia, Raja Grafindo Persada, Jakarta, 2013. 